\title{
Membangun Good Governance Di Lembaga Amil Zakat, Infaq dan Sadaqah (LAZ): Pengalaman Dua LAZ Besar di Indonesia
}

\author{
Ahim Abdurahim, Hafiez Sofyani, Sigit Arie Wibowo \\ Universitas Muhammadiyah Yogyakarta \\ hafiez.sofyani@umy.ac.id
}

\begin{abstract}
This study aims to explore experiences of two big LAZs in Indonesia, namely Lazis Based on Islamic Organization X and Rumah Zakat in complying requirements as a good governance Lazis, with reference to Religion Ministerial Decree (Keputusan Menteri Agama/KMA) 333/2015 about Guidance on Giving Permit Establishment of Amil Zakat Institute and Statement of Financial Accounting Standards (PSAK) No. 109 on Accounting for Zakat and Infak/Alms. Specifically, this study was conducted with interview and observation techniques. This study indicate hat there are several points of the requirements that become obstacles, namely: Registered as an Islamic social institution that manages the field of education, da'wah and social or institutional bodies law, Having a planned program plan and trstruktur, Have the technical, administrative and financial skills to carry out its activities, Have state health insurance (BPJS) and employment or other insurance for its employees, and able to raise funds at least 50 billion for LAZNAS. From the various obstacles that arise, the two LAZ has a similar pattern in solving them, namely by adopting the practice of New Public Management, synergy with various parties, and utilize the progress of information technology by building an e-donation
\end{abstract}

Keywords: Lembaga Amil Zakat (LAZ), Good Governance, New Public Management

\begin{abstract}
Abstrak
Penelitian ini bertujuan untuk mengeksplorasi pengalaman dua LAZ besar di Indonesia, yakni Lazis Berbasis Ormas Islam X dan Rumah Zakat dalam memenubi persyaratan sebagai Lazis ber-tata kelola yang baik, dengan mengacu pada KMA 333 tabun 2015 tentang Pedoman Pemberian Izin Pembentukan LAZ dan Pernyataan Standar Akuntansi Keuangan (PSAK) No.109 tentang Akuntansi Zakat dan Infak/Sedekah. Penelitian ini dilakukan dengan teknik wawancara dan observasi. Hasil penelitian menunjukkan terdapat beberapa persyaratan yang menjadi kendala, yakni: Terdaftar sebagai lembaga kemasyarakatan Islam yang mengelola bidang pendidikan, dakwab dan sosial atau lembaga berbadan bukum, Memiliki rencana program yang terencana dan trstruktur, Memiliki kemampuan teknis, administratif dan keuangan untuk melaksanakan kegiatannya, Memiliki jaminan BPJS kesehatan dan ketenagakerjaan atau asuransi lainnya bagi para pegawainya, dan Sanggup menghimpun dana minimal 50 milyar untuk LAZNAS. Dari berbagai kendala yang muncul, kedua LAZ memiliki pola yang hampir sama dalam menyiasatinya, mengadopsi praktik New Public Management, sinergi dengan berbagai pibak, memanfaatkan kemajuan teknologi informasi.
\end{abstract}

Kata Kunci: Lembaga Amil Zakat (LAZ), Good Governance, New Public Management

Permalink/DOI: http://dx.doi.org/10.18326/infsl3v12i1.45-64 


\section{Pendahuluan}

Praktik pengelolaan zakat yang dilakukan oleh Lembaga Amil Zakat (LAZ) memasuki babak baru setelah disahkannya Keputusan Menteri Agama (KMA) No. 333 Tahun 2015 tentang Pedoman Pemberian Izin Pembentukan Lembaga Amil Zakat. KMA tersebut dibuat dalam rangka memperkuat kedudukan LAZ dan juga sebagai tuntutan kebutuhan agar LAZ menjalankan praktik tata kelola organisasi yang profesional serta mengarah kepada konsep New Public Management (NPM). Inisiasi ini dinilai sangat rasional, mengingat terdapat dugaan dan kecurigaan di tengah masyarakat mengenai praktik LAZ yang kadang dijadikan tempat pencucian uang dan juga LAZ yang dimanfaatkan oleh pihak tertentu untuk mengumpulkan sejumlah dana, namun tidak disalurkan kepada masyarakat yang membutuhkannya (www.batamtoday.com, 2016), bahkan diduga untuk mendanai aksi terorisme (Beik, 2014). Untuk itulah, menjadi sangat mendesak agar dibuat suatu regulasi yang mengatur legalitas operasi dari suatu LAZ yang juga mengatur praktik tata kelola yang baik, yakni melalui instrumen yang dijalankan di lembaga kementerian agama.

Meskipun memiliki tujuan yang baik, KMA yang dikeluarkan tersebut ternyata memicu beberapa masalah di masyarakat. Salah satu contohnya yakni, di dalam KMA tersebut dijelaskan terdapat tiga tingkatan LAZ, yakni Nasional (LAZNAS), Provinsi (LAZPROV) dan Kabupaten/Kota (LAZKAB atau LAZKOT). Setiap tingkatan memiliki syarat minimal jumlah kinerja penghimpunan dana filantropi yang berbeda-beda, yakni Rp 50 miliar untuk LAZ Nasional, Rp 20 miliar untuk LAZ provinsi, dan Rp 3 miliar untuk Laznas Kabupaten/kota (www.republika.com, 2015). Faktanya, di lingkungan masyarakat banyak terdapat LAZ yang masuk dalam kategori kecil sehingga tidak memiliki kemampuan untuk mengumpulkan dana dengan batasan minimal yang ditetapkan oleh menteri agama tersebut, seperti berbagai LAZ yang dikelola oleh amal usaha Berbasis Ormas Islam X, sekolahan, rumah sakit, dan lain sebagainya.

Di sisi lain, eksistensi LAZ kecil yang dimaksud sudah cukup lama dan memiliki keseriusan dalam pelaksanaan program kerjanya. 
Adanya KMA tersebut tentu akan menjadi penghambat bagi operasi LAZ-LAZ kecil tersebut di kemudian hari. Hal ini menjadi isu menarik untuk dikaji dalam rangka menemukan jalan keluar agar LAZ-LAZ yang ukurannya kecil tetapi memiliki dampak cukup berarti di tengah masyarakat ini dapat memperoleh legalitas dari kementerian agama dalam menjalankan kegiatannya. Tidak hanya masalah regulasi administrasi dan tata kelola yang baik berasas syariah (good sharia governance), LAZ juga kerap bermasalah dalam hal standar pelaporan keuangan dan paraktik akuntabilitas serta transparansi. Pasalnya, LAZ yang belum berizin belum mendapatkan audit oleh lembaga berkompeten, baik untuk audit aspek kinerja,keuangan, kinerja non keuangan maupun kinerja syariat (lihat: Istutik, 2013; Endahwati; 2014).

Penelitian mengenai permasalahan yang dihadapi LAZ dalam upaya menyesuaikan diri dengan regulasi yang berlaku, dalam hal ini khususnya KMA 333 tahun 2015 dan juga akuntabilitas dan transparansi pelaporan keuangan yang mengacu pada PSAK 109 secara komprehensif dalam satu isu penelitian belum pernah sama sekali dilakukan. Penelitian sebelumnya terkait LAZ hanya membahas mengenai ketaatan pada standar pelaporan keuangan sesuai dengan PSAK 45 atau 109 atau konsep akuntabilitas vertikal dan horizontal LAZ (Triyuwono dan Roekhudin, 2000; Baroya, 2005; Heryani, 2005; Riyadi, 2006; Mahmudah, 2007; Prayitno, 2008; Amerieska, 2009; Ma'sum, 2009). Berangkat dari hal tersebut, maka sangat penting dan mendesak sekali agar dilakukan suatu penelitian untuk menjawab tantangan yang dihadapi oleh LAZ dan juga Kemenag dalam rangka percepatan pertumbuhan jumlah LAZ yang mendapatkan legalitas dari kementrian agama. Legalitas yang dimaksud di sini tidak hanya sebatas legalitas formil, tetapi juga sarat dengan unsur good sharia governance dan konsep New Public Management di dalam tubuh LAZ itu sendiri. Selain itu, lebih khusus penelitian ini juga berkepentingan dalam rangka penguatan lembaga Lazis Berbasis Ormas Islam X yang menjadi payung Aal Usaha Berbasis Ormas Islam X (AUM) dalam hal mengurusi aktifitas filantrofi di kalangan warga Berbasis Ormas Islam X khususnya dan Masyarakat Indonesia pada umumnya. 
Manfaat praktis dari penelitian ini adalah menemukan permasalahan pada upaya legaliasi LAZ di lingkup Daerah Istimewa Yogyakarta. Selanjutnya, dari temuan permasalahan tersebut, maka dapat dirumuskan suatu model pengembangan LAZ agar dapat direkomendasikan menjadi LAZ yang mendapat legalitas dari kementerian agama. Sementara dari segi teoritis, penelitian ini dapat memberikan tambahan literatur konsep tata kelola yang baik berasas syariah (good sharia governance) dan New Public Management bagi organisasi publik khususnya LAZ.

Sedangkan luaran dari penelitian ini adalah suatu materi atau konsep bagaimana model pengembangan LAZ supaya dapat direkomendasikan menerima legalitas dari kementerian agama dan model (materi) Good Sharia Governance (GSG) dan New Public Management yang dapat diimplementasikan di lembaga LAZ. Materi ini selanjutnya dapat digunakan untuk kegiatan Tri Dharma yang lain bagi dosen Akuntansi UMY, yakni skema pengabdian masyarakat. Selain itu, hasil penelitian ini juga dapat diajukan ke jurnal terakreditasi agar dapat menjadi rujukan referensi bagi kalangan akademisi dalam pengembangan lanjutan lembaga publik, khususnya LAZ.

Berdasarkan latar belakang penelitian yang dipaparkan, maka masalah tujuan penelitian ini adalah: Bagaimana kondisi terkini mengenai kriteria pemenuhan syarat menjadi LAZ berlegalitas sesuai KMA 333 tahun 2015?, Apa saja hambatan dari LAZ terkait pemenuhan syarat menjadi LAZ berlegalitas sesuai KMA 333 tahun 2015?, Apa saja hambatan dari LAZ dalam memenuhi transparansi dan akuntabilitas sesuai PSAK 109?, Bagaimana model LAZ yang memenuhi syarat menjadi LAZ berlegalitas sesuai KMA 333 tahun 2015 serta akuntabilitas dan transparansi sesuai PSAK 109?

\section{Metode Penelitian}

Jenis penelitian ini adalah penelitian kualitatif dengan pendekatan deskriptif investigatif. Pelaksanaan penelitian di lapangan didesain untuk melakukan investigasi terkait permasalahan yang muncul dalam tata kelola LAZ khususnya mengacu pada standar pelaksanaan 
LAZ yang berlaku di Indonesia, baik dari segi regulasi administratif seperti yang tertuang pada Undang-Undang No. 232011 tentang pengelolaan zakat, Peraturan Menteri Agama No. 522014 tentang syarat dan tata cara perhitungan zakat mal dan fitrah, dan Keputusan Menteri Agama No. 3332015 tentang pedoman pemberian izin pembentukan badan amil zakat, maupun regulasi pelaporan akuntansi yang berkaitan dengan aspek ketaatan akuntabilitas dan transparansi sebagaimana yang diatur oleh Pernyataan Standar Akuntansi Keuangan (PSAK) Nomor 109 tentang Akuntansi Zakat dan Infak/Sedekah.

Fokus masalah yang akan diinvesitigasi adalah: 1) kelemahan LAZ dari segi perencanaan dan pelaksanaan program kerja; 2) kendala tata kelola; 3) kendala pelaporan keuangan. Selanjutnya, beranjak dari temuan investigasi tersebut, maka akan dirumuskan suatu model pengembangan LAZ agar memenuhi dan sesuai dengan standar regulasi yang berlaku guna selanjutnya dapat diusulkan menjadi LAZ yang mendapatkan Surat Ketetapan Kementrian Agama (SK Kemenag) baik yang berskala Nasional, Provinsi maupun Kabupaten/Kota.

Objek dari penelitian ini adalah LAZ yang belum terdaftar di Kemenag yang ada di Kota Yogyakarta. Analisis pada penelitian ini akan ditujukan pada aspek tata pamong (governance) dari LAZ yang menjadi objek penelitian, meliputi: Legalitas, Struktur Organisasi, Kualitas Sumber Daya Manusia, Perencanaan Program Kerja, Pelaksanaan Kerja, Manajemen Data, dan Pelaporan (termasuk di dalamnya akuntabilitas, transparansi, dan ketaatan pada PSAK 109). Data pada penelitian ini adalah data primer, yaitu hasil wawancara yang diperoleh dari para informan penelitian dan hasil observasi lapangan terkait Legalitas, Struktur Organisasi, Kualitas Sumber Daya Manusia, Perencanaan Program Kerja, Pelaksanaan Kerja, Manajemen Data, dan Pelaporan LAZ. Sedangkan informan dari penelitian ini yakni: pertama, adalah para ketua atau manajer LAZ (ketua/manajer).

Data diperoleh dengan melakukan wawancara kepada para informan dan melakukan observasi di situs penelitian seperti: struktur organisasi, latar belakang pendidikan pengurus LAZ, dokumentasi 
dan pengelolaan data baik keuangan maupun non keuangan. Teknik wawancara yang dipakai adalah wawancara semi-terstruktur dan terbuka, sambil merekamnya dengan audio recorder, lalu mentranskripnya (Creswell, 2010). Analisis data dilakukan dengan pendekatan analisis tematik deduktif yaitu metoda analitik dalam rangka menganalisis data kualitatif dengan tahapan identifikasi, analisis dan melaporkan pola atau tema yang terdapat di dalam data (Braun dan Clarke, 2006).

Analisis tematik sendiri merupakan salah satu klasifikasi dari teknik analisis isi (content analysis). Temuan dari hasil wawancara dan obeservasi akan menghasilkan suatu simpulan terkait dinamika pengeloalan LAZ yang meliputi: 1) kelemahan LAZ dari segi perencanaan dan pelaksanaan program kerja; 2) kendala tata kelola; 3) kendala pelaporan keuangan. Pengujian pada realibilitas dan validitas dari data wawancara yang sudah terkumpul dilakukan dengan prosedur sebagai berikut; petama, pemeriksaan kembali hasil transkrip. Kedua, melakukan tanya-jawab dengan sesama rekan peneliti (peer de-briefing) untuk meningkatkan keakuratan hasil penelitian (Creswell 2010).

\section{Hasil Dan Pembahasan}

Penelitian ini bertujuan untuk menjawab empat rumusan masalah sebagaimana yang dipaparkan pada bagian awal paper ini. Untuk memudahkan dalam memetakan jawaban penelitian, karenanya temuan penelitian disusun secara berurutan berdasarkan poin-poin rumusan masalah tersebut. pada awalnya penelitian ini direncanakan diselenggarakan di beberapa LAZ yang ada di Daerah Istimewa Yogyakarta, yakni:

1. LAZ Masjid Syuhada

2. LAZ Yayasan Al-Azhar

3. LAZ Universitas Islam Indonesia

4. NU-care Lazisnu

5. Baznas

6. Sompet Dhuafa

7. Pusat Zakat 
8. Rumah Zakat

9. Lazis Berbasis Ormas Islam X (Lazis X)

Namun, karena terkait masalah kesediaan LAZ dalam menerima tim peneliti, akhirnya LAZ yang dapat diteliti sejauh ini hanya dua, yakni Lazis X dan Rumah Zakat yang notabene dua LAZ ini sudah memiliki ijin legalitas dari Kemenag. Meskipun hanya dua LAZ ini yang kemudian dapat diteliti, akan tetapi temuan penelelitian ini sangat kontributif dan patut menjadi masukan dalam pengembangan LAZ lain untuk menjadi LAZ yang berbasis manajemen modern dan profesional. Selain itu, berbagai kendala dan keterbatasan yang dihadapi oleh dua LAZ ini dalam sejarah perjalanannya dapat dijadikan masukan berarti bagi LAZ lain yang masih berkembang. Untuk memudahkan pembaca dalam memahami isi dari hasil penelitian ini, maka dibuat kodifikasi yang merujuk pada informan sebagaimana pada Tabel 1.

\section{Tabel 1.}

Kodifikasi Informan

\begin{tabular}{cccc}
\hline Nama LAZ & Informan & Jabatan & Kode \\
\hline Lazis Berbasis & Bapak HL & Ketua Lazis X Pusat & LM \\
Ormas Islam X & Manager Cabang & \\
Rumah Zakat & Ibu W & $\begin{array}{c}\text { Daerah Istimewa } \\
\text { Yogyakarta }\end{array}$ & RZ \\
\hline
\end{tabular}

Kondisi terkini mengenai kriteria pemenuhan syarat menjadi $L A Z$ berlegalitas sesuai KMA 333 tahun 2015?

Baik Lazis X dan Rumah Zakat saat ini telah memiliki legalitas dari kemenag sesuai KMA 333/2015. Kedua LAZ ini masuk dalam kriteria LAZ Nasional (Laznas). Adapaun syarat untuk mendapatkan legalitas dapat disimak pada BAB 2 paper ini. Dari hasil wawancara denga informan, semua kriteria yang dimuat pada KMA 333/2015 sudah terpenuhi, sehingga Lazis $\mathrm{X}$ dan Rumah Zakat berhak mendapatkan legalitas tersebut. 
Hambatan dari LAZ terkait pemenuban syarat menjadi LAZ berlegalitas sesuai KMA 333 tahun 2015

Dari hasil wawancara ditemukan beberapa hambatan yang dihadapi Lazis X dan Rumah Zakat dalam upaya memenuhi syarat legalitas KMA 333/2015. Permasalahan-permasalahan itu yakni: pertama, Baznas sebagai lembaga pemberi rekomendasi legalitas faktanya di lapangan tidak seragam dan sepemahaman terkait kebijakan KMA 333 2015. Karenanya, kadang membingungkan LAZ yang mengajukan usulan (LM). Hal ini juga didukung oleh argumen dari RZ bahwa di beberapa daerah syarat pengajuan legalitas sangat ketat dan saklek, tetapi di Yogyakarta ada sedikit pemakluman. Misalnya, untuk poin LAZ harus terdaftar sebagai lembaga kemasyarakatan (ormas) Islam yang mengelola bidang pendidikan, dakwah dan sosial atau lembaga berbadan hukum sebagaiman yang tertian dalam BAB II KMA 333 tahun 2015. Akan tetapi karena faktanya tidak semua LAZ dimotori oleh ormas Islam, maka Baznas Yogyakarta memberikan kelunakan untuk poin tersebut dengan catatan LAZ yang mengajukan benar-benar LAZ yang memiliki komitmen memaslahatkan ummat dengan didukung adanya persyaratan-persyaratan lain yang lengkap, seperti ada AD/ ART, struktur organisasi, program yang jelas, dsb.

Hambatan kedua adalah, ketidaksetaraan kapabilitas dan kinerja Sumber Daya Manusia (SDM) pada Laz cabang yang ada di daerah-daerah (LM). Di lapangan kadang kala level kota/kabupaten memiliki kinerja pengelolaan program yang lebih bagus daripada di wilayah atau provinsi. Akhirnya, hal ini berdampak pada masalah administrasi (LM). Poin ini berkaitan dengan syarat memiliki rencana program yang terencana dan terstruktur. Pada awalnya program kerja yang ada di Lazis X dinilai belum terstruktur dan terintegrasi. Hal ini berkaitan erat dengan kompetensi SDM dari LAZ di tiaptiap cabang. Ketika SDM tidak memiliki kesetaraan kompetensi dan kinerja, maka program kerja akan berjalan secara kurang baik.

Hambatan ketiga masih berkaitan dengan program yang terstruktur, yakni LAZ kadang masih menghadapi kebingungan dalam menjalankan operasional lazis karena belum ada kebijakan, pedoman dan Standar Operasional Prosedur (SOP) yang kuat. 
Karenanya ,maka perlu untuk merumuskan ini sehingga secara manajemen dan tata usaha administrasi menjadi lebih rapi. Sehingga pengajuan LAZ berlegalitas akan semakin mudah (LM).

Hambatan keempat yang juga masih berkaitan dengan syarat KMA 333/2015 poin program yang terstruktur adalah Program kurang tertata karena belum ada mekanisme anggaran berbasis kinerja (LM). Karena tidak banyak orang yang berlatar belakang manajemen dan akuntansi, maka pada fase awal Lazis $\mathrm{X}$ penyusunan program kerja kerap kali tidak tersusun dengan baik. Spesifiknya, belum ada formulasi target-target capaian kinerja secara kuantitatif. Perencanaan masih bersifat tradisional, misalnya selama setahun akan melaksanakan kegiatan apa saja, tetapi berapa anggaran pendapatan dan penyaluran serta rincian kegiatan belum dibuat secara detail. Pendekatan perencanaan dan penganggaran secara tradisional ini mengakibatkan LAZ mengalami kesulitan saat proses implementasi, pelaporan dan evaluasi dari proker yang telah dijalankan (LM).

Hambatan kelima masih terkait dengan karakteristk Lazsimu yang berada di bawah ormas Berbasis Ormas Islam X. Fakta di lapangan menunjukkan bahwa peraturan internal ormas Berbasis Ormas Islam X tentang Lazis X tidak sejalan dengan KMA 333/2015 dan Berbasis Ormas Islam X belum merespon tentang kondisi ini. Sebagai contoh, Lazis X harusnya berdiri sendiri sebagai suatu entitas, bukan majlis sebagaimana yang berjalan saat ini. Dengan berdiri sbagai entitas, maka Lazis $\mathrm{X}$ secara hokum memiliki kedudukan tersendiri dan memiliki hak otonomi. Dengan demikian operasional Lazis $\mathrm{X}$ akan berjalan secara independen sehingga kontrol dan intervensi dari Lazis X pusat terhadap Lazis X di semua cabang akan lebih kuat dan ditaati. Namun, fakta yang ada sekarang Lazis cabang dipilih dan ditunjuk oleh PP Berbasis Ormas Islam X. Sehingga hal ini memunculkan dilematis organisasi berupa dualism pucuk pimpinan bagi Lazis X cabang, apakah Lazis X pusat ataukah PP Berbasis Ormas Islam X. Kondisi ini memunculkan ambiguitas aterutama terkait kebijakan dari siapa yang harus ditaati. Akibatnya intervensi kendali organisasi cabang terpecah dan menjadi lemah (LM). 
Hambatan keenam, masih khusus di Lazis X, yakni paradigma pengurus ormas masih menilai bahwa mengurus zakat tidak benar kalau harus digaji besar (LM). Padahal hal ini akan berkaitan dengan motivasi dan kinerja para pegawai LAZ. Pengurus harian Lazis X sendiri menilai seharusnya para pegawai dibayar paling tidak sesuai Upah Minimum Regional (UMR), dan hal ini sebenarnya sebagaimana diatur oleh KMA 333/2015. perbedaan perspektif antara eksekutif (Pimpinan Berbasis Ormas Islam X) dan pengurus harian inilah yang kemudian juga berpengaruh terhadap program kerja yang berjalan. Belum ada mekanisme insentif berbasis kinerja. Karena menilai lazis harus ikhlas. Kondisi ini sangat jauh berbeda dengan di Rumah Zakat dimana mereka berpendapat karena organisasi dijalankan secara professional, maka sudah sepatutnya pegawai diberi penghargaan sesuai dengan profesionalitas itu (RZ). Pegawai yang ada sudah mulai kekurangan. Mereka merasa job overload karena pekerjaan Lazis X banyak sekali. Sementara gaji masih kecil.

Hambatan ketujuh adalah terkait poin KMA 333/2015 mengenai Laznas harus memiliki pegawai sekurang-kurangnya 40 orang dan ber-BPJS. Karena harus ber-BPJS maka itu konseuensinya gaji para pegawai harus sesuai UMR. Hal ini menjadi masalah cukup signifikan bagi LAZ karena terkait dengan permasalahan sebelumnya, yakni adanya pandangan eksekutif Berbasis Ormas Islam X yang menilai bahwa gaji pegawai LAZ "tidak boleh" tinggi (LM). Sementara di Rumah Zakat, hambatan terkait poin ini adalah sulit dalam mencari karyawan karena sudah menajdi rahasia umum bahwa bekerja di LAZ itu harus ikhlas karena gajinya kecil. Akan tetapi kondisi sekarang sudah jauh berbeda dimana sudah mulai banyak orang yang menanyakan lowongan pekerjaan di Rumah Zakat. Jal ini tidak lepas dari lembaga yang terus tumbuh besar dengan disertai perbaikan-perbaikan konsep manajemen dan tata kelola modern, termasuk dalam hal profesionalisme pemberian reward kepada pegawai.

Hambatan kedelapan adalah adanya job overload yang terjadi di kalangan pegawai. Hal ini dikarenakan pada awal-awal berdiri LAZ tidak memiliki banyak pegawai yang benar-benar peggawai tetap di LAZ. Sementara pekerjaan LAZ sangat banyak, mulau dari 
mengumpulkan uang, menyusun dan melaksanakan program, hingga membuat pelaporan serta evaluasi program. Pada akhirnya, hal ini berakibat pada fokus ke akuntabilitas maish kurang (LM).

Hambatan ke Sembilan adalah syarat membangun kantor cabang di seluruh Indonesia bagi Laznas (RZ). Sebagai Laznas, pemerintah mengharapkan seluruh provinsi diadakan kantor cabang wilayah agar program kerja yang dijalankan dapat menjangkau seluruh wilayah di Indonesia. Namun, fakatnya tidak semua wilayah Indonesia punya potensi zakat yang besar khususnya di daerah yang minoritas muslim. Sementara itu, untuk membangun kantor nilai investasi yang harus disiapkan sangat besar dan aspek costbenefit-nya tidak memenuhi. Akibatnya meski berpredikat Laznas, Rumah Zakat masih belum mampu memenuhi ekspektasi besar dari pemerintah. Untungnya, untuk poin ini pemerintah dapat memaklumi dan tidak menjadikannya sebagai penghambat dalam proses pengurusan legalitas LAZ.

Kendala terakhir (kesepuluh) adalah adanya mindset masyarakat yang tidak sejalan dengan program yang dijalankan LAZ (RZ). Program yang dibentuk oleh Rumah Zakat adalah program menyeluruh bagi keluarga yang kurang mampu, misalnya program sekolah anak yatim (tidak memiliki Bapak). Biasanya anak yatim ini diiringi dengan lemahnya ekonomi keluarga dalam kondisi sang Ibu tidak menikah lagi. Lemahnya ekonomi ini dikarenakan biasanya sang Ibu tidak memiliki skill untuk berwirausaha secara baik. Karenanya, selain memberikan bantuan untuk sekolah anak yatim, Rumah Zakat juga mengadakan pemberdayaan ekonomi bagi orang tua-orang tua yang kurang mampu tadi. Akan tetapi kadang mereka tidak benar-benar mau diberdayakan karena mungkin semangat mandiri yang kurang kuat. Selain program semacam itu, ada juga program bantuan modal untuk berwirausaha. Namun sering kali pada emplemantasinya dana tidak sesuai akad, sehingga akhirnya bantuan dihentikan oleh Rumah Zakat dan implementasi program jadi tidak sesuai rencana. Kejadian-kejadian semacam ini meskipun tidak berkaitan langsung dengan syarat legalitas LAZ tetapi berpengaruh terhadap poin memiliki rencana program yang terencana dan trstruktur (RZ). 
Hambatan dari LAZ dalam memenubi transparansi dan akuntabilitas sesuai PSAK 109

Terkait aspek keakuntansian, khususnya dalam hal pelaporan keuangan, salah satu hambatan yang dihadapi Lazis $\mathrm{X}$ ada adalah karena belum adanya Sistem Informasi Akuntansi (SIA) berbasis software, sementara Lazis X mempunyai banyak cabang, maka sulit untuk menyusun laporan keuangan konsolidasian. Kondisi ini selanjutnya menjadikan laporan keuangan belum dapat diaudit (LM). Sementara dari pihak Rumah Zakat tidak menemui kendala berarti mengingat mereka telah memiliki SIA.

Model LAZ yang memenubi syarat menjadi LAZ berlegalitas sesuai KMA 333 tabun 2015 serta akuntabilitas dan transparansi sesuai PSAK 109

Dari berbagai hambatan yang dihadapi Lazis X dan Rumah Zakat, berikut beberapa hal yag telah dan akan dilakukan oleh kedua LAZ tersebut guna meningkatkan kualitas praktik pengelolaan dan tata kelola LAZ sehingga mudah untuk mendapatkan legalitas Kemenag sesuai KMA 333/2015.

Dalam rangka mengatasai kebingungan oleh manajemen dalam menjalan program kerja di lapangan, maka proses perenanaan harus benar-benar dilakukan sebaik mungkin dengan mengacu pada model praktik New Public Management. Ada dua hal pokok yang menjadi perhatian LAZ, yakni dirumuskannya peraturan atau kebijakan, pedoman dan SOP yang kuat, dan dijalankannya anggaran berbasis kinerja. Dengan adanya SOP yang detail dan terpernci sampai menyentuh pada aspek teknis, maka pegawai LAZ, khususnya yang baru bergabung, tidak akan mengalami kebingungan untuk menjalankan program kerja dan kegiatan. Selain itu, dengan praktik perencanaan dan penganggaran berbasis kinerja maka program dan kegiatan LAZ akan dirumuskan secara rinci sampai menyentuh pada aspek target capaian dan indikator kinerja dalam satuan angka rupiah yang jelas. Hal ini juga dapat dikaitkan dengan mekanisme reward bagi pegawai. Dengan demikian upaya pencapaian kinejra LAZ akan dapat diraih secara terukur baik dari segi waktu maupun satuan rupiah. 
Untuk meningkatkan kinerja dan program yang terstruktur, Lazis X dan Rumah Zakat membangun model program terintegrasi, misal bantuan sekolah bagi anak yatim sekaligus membina ekonomi keluarganya. Selain itu, kegiatan juga dirancang agar dapat bersinergi dengan beberapa majelis dan lembaga lain yang kredibel, atau LSM. Sehingga LAZ dapat berfokus pada pengumpulan potensi infaq dan zakat saja. Sementara untung tanggung jawab penyaluran dana ada pada LSM atau lembaga lainya yang bersinergi dengan LAZ.

Supaya memiliki akuntabilitas yang baik dan auditbale maka LAZ harus mengacu pada Pernyataan Standar Akuntansi Keuangan No 109 tentang LAZIS. Namun untuk dapat memenuhi aturan ini, LAZIS perlu membentuk tim khusus baik sebagai pelaksana maupun pengawas aspek akuntabilitas dan semua terkait keakuntansian. Selain itu perlu direformulasi kebijakan dan aturan terkait entitas LAZ, khususnya terkait hubungan LAZ pusat dan cabang di wilayah (provinsi) serta membangun SIA agar hambatan-hambatan terkait akunabilitas dan akuntansi dapat teratasi dengan baik. LAZ juga sudah sepatutnya mempunyai auditor internal, sehingga masalah keakuntansian, pengelolaan dan tatat kelola baik terkait program dan keuangan dapat diawasi, sehingga berjalan dengan baik. Karenanya, peran auditor internal ini dapat disimpulkan tidak hanya soal pelaporan keuangan saja, tetapi juga penganggaran, implementasi program, siste pengendalian internal, dan pelaporan (akuntabilitas dan transparansi. Untuk program di lapangan, harus ada supervisor mustahiq supaya terawasi dan terkontrol. Untuk merancang sistem pengelolaan dan tata kelola berbasis new public management ini, maka LAZ harus melibatkan akademisi dan pengawas di bidang akuntansi yang dapat dilakukan dengan bersinergi dengan universitas, contohnya Lazis $\mathrm{X}$ dan beberapa Perguruan Tinggi Berbasis Ormas Islam X yang ada di Indonesia (LM).

Dalam hal menyiasati agar dana yang terkumpul minimal 50M, hal pertama yang dilakukan adalah dengan mewujudkan siste tata kelola yang baik dan bersih. Dari sini, maka akan tumbuh kepercayaan oleh masyarakat luas selaku stakeholders, sehingga mereka akan bersedia dan mau untuk menyalurkan infaq dan zakat 
melalui LAZ (RZ). Strategi lainnya adalah dengan cara berkolaborasi dengan organisasi seafiliasi seperti yang dilakukan oleh Lazis X. Sebagai contoh Lazis X menjadi LAZ yang mengelola zakat dan infaq dari dosen, mahasiswa, guru, murid, wali murid, dokter, perawat, dan semua pihak yang bekerja di Amal Usaha Berbasis Ormas Islam X seperti Perguruan Tinggi, Sekolah, dan Rumah Sakit. Strategi jitu lainnya adalah sebagaimana yang dilakukan Lazis X dan Rumah Zakat yakni dengan membangun sistem donasi via daring (e-donation). Dengan demikian maka aktivitas pengumpulan dana infaq dan zakat tidak selalu harus dilakukan melalui kantor cabang.

Dalam rangka menambah tenaga kerja di LAZ dan mengurangi job overload pegawai, maka LAZ harus membangun budaya kerja kondusif, misalnya masalah berpakaian, ketertiban, dan masalah kesehatan seperti dilarang merokok. Selain itu segala bentuk konsep good governance dan new public management modern senantiasa diadopsi oleh LAZ. Dengan demikian LAZ sebagai akan nampak sebagai lembaga profesional yang dilirk pencari kerja.

Dalam rangka menyiasati kebijakan semua Laznas harus memiliki minimal 40 orang pegawai dengan gaji UMR dan berBPJS, maka Lazis X menunjuk orang-orang yang sudah ber-BPJS dari instansi utama mereka bekerja, misalnya di Perguruan Tinggi, Rumah Sakit, Sekolah, dan Amal Usaha Berbasis Ormas Islam X (AUM) lainnya. Praktik ini rupanya mendapat pemakluman dari Baznas.

Terakhir, terkait kendala mindset masyarakat selaku mustahiq yang kadang kala tidak sejalan dengan program yang telah dirumuskan LAZ, seperti uang digunakan tidak sesuai akad di awal, atau mereka meminta berhenti mendapat bantuan dari LAZ, maka pihak LAZ memberikan pemahaman secara persuasive agar mustahiq dapat bersikap kooperatif. Selain itu, LAZ juga membentuk tim supervise untuk mendampingi para mustahiq agar program yang diberikan kepada mustahiq dapat berjalan dengan baik.

Dari temuan penelitian di Lazsimu dan Rumah Zakat, maka dapat dipetakan hambatan ketika dituntut memenuhi persyaratan untuk menjadi LAZ berlegalitas dari Kemenag, sebagaimana disajikan pada Tabel 2. 
Tabel 2.

\section{Matriks Syarat, Hambatan dan Tindakan Mengatasi Hambatan}

\begin{tabular}{|c|c|c|c|}
\hline No. & $\begin{array}{l}\text { Poin KMA } \\
\text { 333/2015 yang } \\
\text { memunculkan } \\
\quad \text { hambatan }\end{array}$ & $\begin{array}{c}\text { Hambatan yang } \\
\text { muncul }\end{array}$ & Tindakan yang dilakukan \\
\hline 1. & $\begin{array}{l}\text { Terdaftar } \\
\text { sebagai lembaga } \\
\text { kemasyarakatan } \\
\text { Islam yang } \\
\text { mengelola bidang } \\
\text { pendidikan, } \\
\text { dakwah dan sosial } \\
\text { atau lembaga } \\
\text { berbadan hukum }\end{array}$ & $\begin{array}{l}\text { Penafsiran Baznas di } \\
\text { beda tempat berbeda }\end{array}$ & $\begin{array}{l}\text { Tidak ada. Namun untuk kasus } \\
\text { Baznas di Yogyakarta mereka } \\
\text { memaklumi jika LAZ tidak dari } \\
\text { lembaga kemasyarakatan (ormas) } \\
\text { Islam }\end{array}$ \\
\hline \multirow[t]{3}{*}{2.} & $\begin{array}{l}\text { Memiliki rencana } \\
\text { program yang } \\
\text { terencana dan } \\
\text { trstruktur }\end{array}$ & $\begin{array}{l}\text { Ketidaksetaraan } \\
\text { kapabilitas dan kinerja } \\
\text { Sumber Daya Manusia } \\
\text { (SDM) pada Laz cabang } \\
\text { yang ada di daerah- } \\
\text { daerah (LM) }\end{array}$ & $\begin{array}{l}\text { Di Lazis X belum dapat teratasi } \\
\text { dengan benar-benar baik. } \\
\text { Sedangkan di Rumah Zakat } \\
\text { sudah tidak terjadi karena } \\
\text { rekrutmen benar-benar dilakukan } \\
\text { secara selektif. }\end{array}$ \\
\hline & & $\begin{array}{l}\text { Perencanaan masih } \\
\text { bersifat tradisional dan } \\
\text { belum berbasis kinerja } \\
\text { (LM) }\end{array}$ & $\begin{array}{l}\text { Lazis X mulai merumuskan } \\
\text { anggaran berbasis kinerja dengan } \\
\text { mengikutsertakan indicator } \\
\text { pengukuran kinerja. }\end{array}$ \\
\hline & & $\begin{array}{l}\text { Mindset masyarakat } \\
\text { yang tidak sejalan } \\
\text { dengan program yang } \\
\text { dijalankan LAZ (RZ) }\end{array}$ & $\begin{array}{l}\text { Sosialisasi secara persuasi kepada } \\
\text { mustahiq terkait program yang } \\
\text { diselenggarakan Ruah Zakat. Untuk } \\
\text { program di lapangan dibentuk } \\
\text { tim supervisor mustahiq supaya } \\
\text { terawasi dan terkontrol (RZ). }\end{array}$ \\
\hline 3. & $\begin{array}{l}\text { Memiliki } \\
\text { kemampuan teknis, } \\
\text { administratif dan } \\
\text { keuangan untuk } \\
\text { melaksanakan } \\
\text { kegiatannya; }\end{array}$ & $\begin{array}{l}\text { LAZ kadang masih } \\
\text { menghadapi kebingungan } \\
\text { dalam menjalankan } \\
\text { operasional lazis, } \\
\text { khususnya terkait } \\
\text { teknis dan aturan main } \\
\text { penyaluran dana yang } \\
\text { terkumpul. Hal ini } \\
\text { dikarenakan belum ada } \\
\text { kebijakan, pedoman } \\
\text { dan Standar Operasional } \\
\text { Prosedur (SOP) yang kuat. }\end{array}$ & $\begin{array}{l}\text { Lazis X membentuk tim untuk } \\
\text { menyusunan Pedoman dan } \\
\text { SOP untuk setiap program dan } \\
\text { kegiatan (LM). } \\
\text { Membangun model program } \\
\text { terintegrasi, misal bantuan } \\
\text { sekolah bagi anak yatim sekaligus } \\
\text { membina ekonomi keluarganya } \\
\text { (RZ) dengan memlibatkan atau } \\
\text { membangun Lembaga Swadaya } \\
\text { Masyarakat (LM dan RZ). }\end{array}$ \\
\hline
\end{tabular}


Poin KMA

No. 333/2015 yang

hambatan

\section{Hambatan yang muncul}

Tindakan yang dilakukan
Peraturan internal ormas tempat LAZ bernanung belum "in line" dengan KMA 333/2015 (LM)

Job overload pegawai sehingga kadang program kerja agak carut marut dalam hal implementasi.
Pengadaan kantor cabang wilayah agar program kerja yang dijalankan dapat menjangkau seluruh wilayah di Indonesia.
Dilakukan upaya koordinasi dan konsolidasi untuk merumuskan kebijakan baru agar tidak menghambat kinerja LAZ.

Baik Lazis X dan Rumah Zakat sudah ada perbaikan khususnya karena adanya perbaikan mekanisme reward (penggajian) sehingga orang luar tertarik untuk bekerja di LAZ. Rumah Zakat juga berfokus menjaga budaya kerja kondusif, misalnya masalah berpakaian, ketertiban, dan masalah kesehatan seperti dilarang merokok. Dari kebijakan ini akan nampak Rumah Zakat sebagai lembaga profesional yang dilirk pencari kerja. Dengan demikian jumlah pegawai semakin bertambah. Karena SDM sudah semakin banyak sehingga job overload agak berkurang.

Terkait keberadaan kantor cabang di tiap provinsi untungnya ada pemakluman dari Baznas karena tidak semua provinsi di Indonesia punya potensi zakat yang tinggi dan memungkinkan di bangun kantor cabang di daerah tersebut, misalnya daerah muslim sebagai minoritas.selain itu hal ini disiasati dengan membangun sistem $e$-donation (donasi via internet/mobile banking). Sehingga muzakki atau orang yang berinfaq tidak harus datang ke kantor, dan daerah tertentu tidak harus ada kantor cabangnnya. Untuk penyaluran dapat berkoordinasi dengan pemda atau LSM setempat. 


\begin{tabular}{|c|c|c|c|}
\hline No. & $\begin{array}{c}\text { Poin KMA } \\
\text { 333/2015 yang } \\
\text { memunculkan } \\
\text { hambatan }\end{array}$ & $\begin{array}{c}\text { Hambatan yang } \\
\text { muncul }\end{array}$ & Tindakan yang dilakukan \\
\hline & & $\begin{array}{l}\text { Terdapat masalah } \\
\text { penyusunan laporan } \\
\text { keuangan konsolidasian } \\
\text { (khusus Lazis X) } \\
\text { karena belum adanya } \\
\text { software dan kesatuan } \\
\text { koordinasi antara pusat } \\
\text { dan cabang. Akibatnya } \\
\text { laporan keuangan } \\
\text { belum auditable. }\end{array}$ & $\begin{array}{l}\text { Lazis X membentuk tim ahli } \\
\text { dewan pengawas Lazis X } \\
\text { (internal auditor) dari Perguruan } \\
\text { Tinggi Berbasis Ormas Islam X } \\
\text { dan tokoh-tokoh Berbasis Ormas } \\
\text { Islam X untuk pengembangan } \\
\text { software dan perumusan } \\
\text { kebijakan keakuntansian. }\end{array}$ \\
\hline 4. & $\begin{array}{l}\text { Memiliki jaminan } \\
\text { BPJS kesehatan dan } \\
\text { ketenagakerjaan } \\
\text { atau asuransi } \\
\text { lainnya bagi para } \\
\text { pegawainya; }\end{array}$ & $\begin{array}{l}\text { Paradigma eksekutif } \\
\text { masih menilai bahwa } \\
\text { mengurus zakat tidak } \\
\text { benar kalau harus digaji } \\
\text { besar. Padahal jika } \\
\text { harus ber-BPJS, maka } \\
\text { gaji harus sesuai UMR } \\
\text { setempat. }\end{array}$ & $\begin{array}{l}\text { Kasus Lazis X masih } \\
\text { menggunakan tenaga kerja dari } \\
\text { aktivis Berbasis Ormas Islam X } \\
\text { yang berstatus BPJS dari instansi } \\
\text { utama tempat bekerja. Untungnya } \\
\text { Basnas dapat memaklumi. } \\
\text { Untuk kasus Rumah Zakat } \\
\text { mereka sudah berjalan secara } \\
\text { professional dimana gaji pegawai } \\
\text { sudah sesuai UMR. }\end{array}$ \\
\hline 5. & $\begin{array}{l}\text { Sanggup } \\
\text { menghimpun dana } \\
\text { minimal } 50 \text { milyar } \\
\text { untuk LAZNAS, } \\
20 \text { milyar untuk } \\
\text { LAPROV dan } \\
3 \text { milyar untuk } \\
\text { LAZKAB atau } \\
\text { LAZKOT. }\end{array}$ & $\begin{array}{l}\text { Sebenarnya tidak ada } \\
\text { kendala pada poin ini } \\
\text { baik Lazis X maupun } \\
\text { Rumah Zakat karena } \\
\text { potensi zakat yang } \\
\text { mereka kumpulkan } \\
\text { diatas Rp 80M. akan } \\
\text { tetapi sebagai LAZ yang } \\
\text { professional keduanya } \\
\text { terus mengoptimalkan } \\
\text { pengumpulan potensi } \\
\text { zakat yang ada agar } \\
\text { kemaslahatan semakin } \\
\text { dapat terwujud. }\end{array}$ & $\begin{array}{l}\text { Peningkatan pengumpuan } \\
\text { potensi zakat dilakukan dengan } \\
\text { membangun sistem e-donation } \\
\text { (donasi via internet/mobile } \\
\text { banking). Sehingga muzakki atau } \\
\text { orang yang berinfaq tidak harus } \\
\text { datang kekantor. }\end{array}$ \\
\hline
\end{tabular}

\section{Simpulan}

Penelitian ini bertujuan untuk mengeksplorasi pengalaman dua LAZ besar di Indonesia, yakni Lazis Berbasis Ormas Islam X dan Rumah Zakat dalam memenuhi persyaratan sebagai Lazis ber-tata kelola yang baik, dengan mengacu pada KMA 333 tahun 2015 tentang 
tentang Pedoman Pemberian Izin Pembentukan Lembaga Amil Zakat dan Pernyataan Standar Akuntansi Keuangan (PSAK) No. 109 tentang Akuntansi Zakat dan Infak/Sedekah. Dari hasil penelitian terdapat beberapa butir persyaratan yang menjadi kendala, yakni: Terdaftar sebagai lembaga kemasyarakatan Islam yang mengelola bidang pendidikan, dakwah dan sosial atau lembaga berbadan hokum, Memiliki rencana program yang terencana dan trstruktur, Memiliki kemampuan teknis, administratif dan keuangan untuk melaksanakan kegiatannya, Memiliki jaminan BPJS kesehatan dan ketenagakerjaan atau asuransi lainnya bagi para pegawainya, dan Sanggup menghimpun dana minimal 50 milyar untuk LAZNAS, 20 milyar untuk LAPROV dan 3 milyar untuk LAZKAB atau LAZKOT. Dari berbagai kendala yang muncul, kedua LAZ memiliki pola yang hampir sama dalam menyiasatinya, yakni dengan mengadopsi praktik New Public Management agar pengelolaan dan tata kelola Lazis dapat berjalan dengan baik. Selain itu dilakukan sinergi dengan berbagai pihak, seperti akademisi dan LSM, serta memanfaatkan kemajuan teknologi informasi dengan membangun sistem $e$-donation untuk mengoptimalkan pengumpulan potensi zakat dan Infaq dari berbagai daerah di Indonesia. Hasil penelitian ini diharapkan dapat menjadi bahan masukan bagi LAZ lain dalam meningkatkan kualitas pengelolaan dan tata kelola, khususnya terkait pengajuan legalitas kepada Kemenag RI yang diatur dalam KMA 333 tahun 2015.

\section{Daftar Pustaka}

Collins, R. 1979. The credential society. New York: Academic Press.

DiMaggio, P. J., dan W. W. Powell. 1983. The Iron cage revisited: Institutional isomorphism and collective rationality in organizational fields. Dalam W. W. Powell dan P. J. DiMaggio (editor). The New institutionalism in organizational analysis (p/ 63-82). Chicago: The University of Chicago Press. 
Fennell, M. L. 1980. The effects of environmental characteristics on the structure of hospital clusters. Administrative Science Quarterly 25 (3): 484-510.

Gudono. 2014. Teori organisasi. edisi 3. Yogyakarta: BPFEYogyakarta.

Batam Today. 2016. Hanya BAZNAS dan LAZ yang Berhak Mengumpulkan Zakat: Awas Amil Zakat Bodong! http:// batamtoday.com/berita-73458-Awas-Amil-Zakat-Bodong!. html diakses Oktober 2016

Beik, I. S. 2014. Urgensi Standarisasi Zakat Internasional. http:// pusat.baznas.go.id/berita-artikel/urgensi-standarisasi-zakatinternasional/

Larson, M. S. 1977. The rise of professionalism: A Sociological analysis. Berkeley: University of California Pres.

Meyer, J. W., dan B. Rowan. 1977. Institutionalized organizations: Formal structure as myth and ceremony. American Journal of Sociology 83 (2): 340-363.

Soelendro, A. 2000. Paradigma Baru Aparat Pengawasan Intern Pemerintah. Konvensi Nasional Akuntansi IV dan Kongres Luar Biasa Ikatan Akuntan Indonesia (IAI).

Sofyani, H., dan R. Akbar. 2013. Hubungan faktor internal institusi dan implementasi sistem akuntabilitas kinerja instansi pemerintah (SAKIP) di Pemerintah Daerah. Jurnal Akuntansi dan Keuangan Indonesia 10 (2): 184-205.

Sofyani, H., \& Akbar, R. (2016). Hubungan karakteristik pegawai pemerintah daerah dan implementasi sistem pengukuran kinerja: Perspektif ismorfisma institusional. Jurnal Akuntansi dan Auditing Indonesia, 19 (2), 153-173.

Wijaya, A. H. C., dan R. Akbar. 2013. The influence of information, organizational objective and targets, and external pressure 
toward the adoption of performance measurement system in public sector. Journal of Indonesian Economy and Business 28: 62-83.

Ulum, I., dan H. Sofyani. 2016. Akuntansi (Sektor) Publik. Yogyakarta: Aditya Media Publishing.

Wibawa, Samodra. 2002. Penjajagan Awal Penerapan'New Public Management'dalam Administrasi Kabupaten." Jurnal Ilmu Sosial dan Ilmu Politik 5, no. 3 (2002): 361-378. 